\title{
PENERAPAN FIREBASE CLOUD STORAGE PADA APLIKASI MOBILE ANDROID UNTUK MELAKUKAN PENYIMPANAN IMAGE LAHAN PERTANIAN
}

\author{
Roosevelt Joshua Gunadi, Radius Tanone, Yos Richard Beeh \\ Program Studi Teknik Informatika, Fakultas Teknologi Informasi, Universitas Kristen Satya Wacana \\ J1. Diponegoro No. 52-60, Salatiga 50711, Indonesia \\ radius.tanone@uksw.edu
}

\begin{abstract}
Speed in overcoming the problem of agriculture in agricultural areas is needed at this time to maintain and increase agricultural production. The use of android mobile phones and the internet is now very widespread in remote villages. Large and secure cloud storage media are needed to store large visual data. This research aims to design a mobile firebase cloud storage application for storing images or photos to firebase, which can be accessed quickly and safely. The method used is descriptive qualitative research and development methods. The results show that the mobile firebase cloud storage application speeds up the cloud storage and analysis of images on firebase cloud storage media and enables image analysis to be carried out without direct contact or without having to visit agricultural areas. This research concludes that the mobile firebase cloud storage application is an indispensable application for storing image data to firebase quickly and for image data analysis to solve farmers' problems without contact or without having to conduct field visits.
\end{abstract}

Keywords - Mobile Firebase Cloud Storage, Android, Agriculture, Analysis

\begin{abstract}
Abstrak - Kecepatan dalam mengatasi masalah pertanian di area pertanian sangat diperlukan saat ini untuk mempertahankan dan meningkatkan produksi pertanian. Penggunaan handphone android dan internet saat ini sudah sangat luas hingga ke pelosok pedesaan. Media penyimpanan yang besar dan aman dibutuhkan untuk menyimpan data-data visual yang besar. Penelitian ini bertujuan merancang aplikasi mobile firebase cloud storage untuk penyimpanan gambar atau foto ke firebase, yang dapat diakses dengan cepat dan aman. Adapun metode yang digunakan adalah metode penelitian dan pengembangan kualitatif deskriptif. Hasil penelitian menunjukkan bahwa aplikasi mobile firebase cloud storage mempercepat penyimpanan dan analisis gambar pada media penyimpanan awan firebase serta memungkinkan analisis gambar dapat dilakukan tanpa bersentuhan langsung atau tanpa harus berkunjung ke area pertanian. Penelitian ini menyimpulkan bahwa aplikasi mobile firebase cloud storage merupakan aplikasi yang sangat diperlukan untuk melakukan penyimpanan data gambar ke firebase dengan cepat serta untuk analisis data gambar untuk pemecahan masalah petani tanpa bersentuhan atau tanpa harus melakukan kunjungan lapangan.
\end{abstract}

Kata kunci - Mobile Firebase Cloud Storage, Android, Pertanian, Analisis

\section{PENDAHULUAN}

Pada era internet saat ini dengan perpindahan data online hampir setiap detik dan produksi data terabite (yang sebagian besar berupa gambar yang diambil oleh kamera telepon selular) setiap harinya di internet, maka masalah tempat penyimpanan yang aman dan dapat diakses sewaktu-waktu dan bukan merupakan media penyimpanan di telepon selular yang sangat terbatas menjadi kebutuhan saat ini. Pertukaran data atau informasi berupa gambar dalam suatu komunikasi atau pertukaran informasi adalah sesuatu yang sangat penting di zaman teknologi yang sangat maju ini.
Handphone dengan basis android saat ini berkembang dengan sangat pesat, membuat aplikasi android yang dapat menampung banyak data menjadi

kebutuhan saat ini, sehingga perlu pemilihan database yang cocok untuk diintegrasikan dengan aplikasi berbasis android yang dibuat. Beberapa database yang biasanya dipakai untuk aplikasi android adalah SQLite, MySQL, dan Firebase [1].

Meningkatnya penggunaan telepon selular yang smartphone memacu pula munculnya layanan penyimpanan awan atau cloud cloud storage, hal ini disebabkan oleh karena telepon selular memiliki keterbatasan pada media penyimpanan internalnya. Media penyimpanan awan ini memberikan solusi ruang penyimpanan yang besar dan dapat diakses dari mana 
saja dan kapan saja dengan melalui berbagai perangkat yang terhubung dengan internet. Layanan penyimpanan awan ini memungkinkan penyimpanan berbagai macam file seperti foto, video, film, dan dokumen tanpa harus khawatir dengan batas penyimpanan pada smartphone dan sekaligus dapat menjamin keamanan data walaupun smartphone rusak.

Penyimpanan awan atau cloud cloud storage adalah penyimpanan data digital dalam komputer server, penyimpanan meliputi banyak server pada beberapa lokasi, dan yang memiliki dan mengelola lingkungan fisik adalah perusahaan hosting. Penyedia cloud storage bertanggung jawab dalam hal menjaga data agar selalu tersedia dan dapat diakses, dan juga lingkungan fisik harus terlindungi dengan baik. Orang atau organisasi dapat menyewa atau membeli dari pengelola cloud storage berbagai kapasitas penyimpanan [2].

Aplikasi web menjadi semakin bergantung pada sejumlah besar database dan data yang tidak terorganisir seperti video, gambar, audio, teks, file dan jenis lainnya sulit bagi Sistem Manajemen Basis Data Relasional (RDBMS) untuk menangani data yang tidak terstruktur. Firebase adalah teknologi yang relatif baru untuk menangani sejumlah besar data tidak terstruktur dalam mengembangkan aplikasi Android [3].

Aplikasi kamera berbasis Android dengan memanfaatkan Internet of Things (IoT) dengan media penyimpanan server memberikan keamanan yang baik terhadap data/gambar yang diambil oleh kamera berbasis android [4]. Demikian halnya dengan media penyimpanan Firebase dengan menggunakan Android Studio dapat memberikan pemberitahuan secara otomatis dan real time [5]. Demikian pula Firebase sangat cocok digunakan dengan aplikasi karena memiliki fitur-fitur yang sangat mendukung, seperti Cloud Messaging, Authentication, Realtime Database, Cloud storage dan lainnya [6], demikian pula untuk penyimpanan data yang cukup besar dan aman, Firebase menjadi salah satu yang direkomendasikan [7], terutama dalam penyimpanan gambar dan informasi pada database firebase [8].

Berdasarkan kebutuhan akan media penyimpanan yang besar dan mudah dilakukan serta cocok diintegrasikan dengan aplikasi berbasis android, maka penelitian ini bertujuan untuk membuat aplikasi dengan media penyimpanan pada cloud. Metode penyimpanan data pada penyimpanan awan (cloud storage) dari hasil kamera berbasis android ini diharapkan dapat menjadi solusi kebutuhan akan media penyimpanan yang besar serta kemudahan dalam akses untuk menyimpan dan mengambil data serta keamanan dalam penyimpanan data.

Rumusan masalah penelitian ini meliputi, bagaimana merancang aplikasi yang mempermudah menyimpan gambar atau foto ke firebase database, dan bagaimana mengakses Firebase untuk melakukan aktivitas download dan upload serta analisis data gambar pada Firebase. Batasan penelitian adalah data yang digunakan adalah data gambar atau foto, aplikasi untuk penyimpanan ke Firebase database yang digunakan adalah aplikasi cloud storage berbasis mobile android, perangkat pembuatan aplikasi yang digunakan adalah Android Studio, sistem database yang digunakan adalah Firebase, aplikasi yang digunakan untuk mengambil gambar atau foto adalah aplikasi kamera handphone pada handphone Android, dan perangkat yang digunakan untuk mengakses dan menampilkan data adalah handphone Android.

Tujuan dari penelitian ini adalah merancang aplikasi Mobile Firebase Cloud storage untuk penyimpanan gambar atau foto ke Firebase, yang dapat diakses dengan cepat dan aman. Adapun manfaat yang diharapkan dari penelitian ini adalah terciptanya suatu aplikasi pada smartphone Android yang bertujuan untuk memudahkan penyimpanan dan pengaksesan data untuk berbagai keperluan dengan cepat dan aman dikemudian hari.

\section{TINJAUAN PUSTAKA}

Pada penelitian yang berjudul Aplikasi Inventori menggunakan Teknologi Firebase (Studi Kasus: PT. Asindo Setiatama), memanfaatkan teknologi Firebase untuk membangun aplikasi web dan mobile berbasis Javascript dan HTML5 yang dapat berjalan pada multi platform mobile, serta Firebase realtime database yang berfungsi menyimpan data, untuk mempermudah serta mempercepat pengolahan data barang, penyimpanan data, dan pengiriman data, serta pembukuan perusahaan [9]. Selanjutnya pada penelitian yang berjudul Penerapan Firebase Realtime Database Pada Prototype Aplikasi Pemesanan Makanan Berbasis Android, memanfaatkan teknologi firebase realtime database berbasis android untuk mempermudah pelanggan dalam hal memesan makanan sehingga tidak perlu menunggu lama dan bahkan dapat melakukan pemesanan sebelum berada di tempat makan tersebut [10]. Selanjutnya pada penelitian yang berjudul Perancangan Aplikasi E-Voting Berbasis Android Dengan Teknologi Firebase (Studi Kasus : Pemilihan Ketua HMP FTI UKSW), memanfaatkan teknologi Firebase realtime database sebagai database, Firebase Authentication sebagai autentikasi user, dan cloud storage sebagai media penyimpanan yang memudahkan mahasiswa untuk berpartisipasi dalam voting melalui smartphone [11].

Penelitian yang telah dilakukan sebelumnya adalah memanfaatkan Firebase sebagai media penyimpanan untuk data yang cukup besar dan juga 
keperluan untuk media penyimpanan yang aman. Penelitian yang dilakukan saat ini adalah selain memanfaatkan media Firebase untuk penyimpanan data yang besar serta aman, juga untuk melakukan pertukaran data visual untuk analisis dan hasil analisis antara petani dan analis pertanian atau penyuluh. Pertukaran data ini akan mempercepat pemecahan solusi masalah pertanian di area pertanian tanpa menunggu kunjungan lapangan oleh penyuluh atau ahli pertanian. Hal ini akan menjadi solusi dalam upaya mempertahankan dan meningkatkan produksi pertanian pada saat bencana atau pandemi.

Android adalah sistem operasi berbasis Linux dirilis secara resmi pada tahun 2007, bersamaan dengan didirikannya Open Handset Alliance, konsorsium dari perusahaan-perusahaan perangkat keras, perangkat lunak, dan telekomunikasi yang bertujuan untuk memajukan standar terbuka perangkat seluler. Android dirancang untuk perangkat bergerak layar sentuh. Awalnya Android dikembangkan oleh Android, Inc., dengan dukungan finansial dari Google, yang kemudian membelinya pada tahun 2005. Ponsel berbasis Android pertama kali dijual pada Oktober 2008.

Android merupakan sistem operasi terbuka di bawah Lisensi Apache, sehingga Android dimungkinkan untuk dimodifikasi secara bebas oleh para pembuat perangkat, operator nirkabel, dan pengembang aplikasi. Fungsionalitas perangkat Android diperluas oleh sejumlah besar komunitas pengembang aplikasi (apps). Umumnya Android ditulis dalam versi bahasa pemrograman Java. Perusahaan berbasis teknologi yang menginginkan sistem operasi berbiaya rendah, bisa dikustomisasi, serta ringan untuk perangkat berteknologi tinggi tanpa harus mengembangkannya dari awal, maka Android merupakan salah satu pilihan terbaik saat ini [12].

Firebase merupakan layanan dari Google untuk memudahkan pengembang aplikasi dalam hal mengembangkan aplikasinya. Firebase memungkinkan pengembang aplikasi untuk fokus dalam mengembangkan aplikasinya tanpa harus mengeluarkan usaha atau upaya yang besar. Firebase hasil evolusi dari Envolve yaitu startup yang didirikan oleh James Tamplin dan Andrew Lee pada tahun 2011. Envolve menyediakan pemrograman aplikasi obrolan daring. Namun ditemukan pula bahwa Envolve juga dimanfaatkan dalam mengirimkan data aplikasi yang bukan merupakan pesan obrolan. Envolve digunakan untuk menyinkronkan data aplikasi seperti status permainan secara real time pada penggunanya. Selanjutnya dalam menjalankannya diputuskan agar sistem obrolan dan arsitektur real time dipisahkan.

Pada April 2012, Tamplin dan Lee mendirikan Firebase sebagai sebuah perusahaan terpisah. Pada
Oktober 2014, Firebase diakuisisi oleh Google, dan kemudian Google mengakuisisi Divshot pada Oktober 2015 dan menggabungnya dengan Firebase. Firebase mengalami perkembangan pesat di Google dengan luasan layanan sehingga menjadi platform terpadu bagi pengembang aplikasi. Saat ini Firebase dapat dikatakan terintegrasi dengan berbagai layanan Google lainnya.

Akuisisi Fabric dan Crashlytics dari Twitter dilakukan oleh Google pada Januari 2017 yang selanjutnya digabungkan ke Firebase. Firebase memiliki fitur Firebase Cloud Messaging, Firebase Authentication, Firebase Remote Config, Firebase Realtime Database, Firebase Cloud storage, Firebase Hosting, Firebase Crash Reporting, Firebase Performance, Firebase Test Lab untuk Android dan iOS, Firebase Notifications, Firebase App Indexing, Firebase Dynamic Links, dan Firebase Invites [13].

Komputasi awan melibatkan pengiriman data, aplikasi, video, gambar melalui internet ke pusat data. Semua layanan, penyimpanan, berbagi data, dan sumber daya sistem lainnya tersedia di cloud untuk penggunaan umum. Proses berbagi dari semua data ini disebut komputasi awan dan sangat terkait dengan konsep Internet of Things (IoT). Internet of Things mengacu pada koneksi internet perangkat [14]. Komputasi cloud dikategorikan dalam tiga kategori yaitu Public Cloud yang tersedia untuk semua, Private Cloud yang tersedia dalam suatu organisasi, dan Hybrid Cloud, yang menggabungkan kedua model arsitektur cloud. Layanan penyimpanan yang tersedia di cloud sangat besar dan mampu menangani aktivitas real time dan pemberitahuan yang diperlukan oleh banyak perangkat IoT [15]. Karena adanya komputasi awan beberapa peralatan industri digantikan oleh Cloud Robotika yang dapat membantu dalam proses otomasi. Tenaga kerja manusia dapat dikurangi sementara efisiensi pekerjaan meningkat karena berbagi data tersedia di penyimpanan awan [16].

\section{METODE PENELITIAN}

Langkah-langkah penelitian dan pengembangan kualitatif deskriptif dalam rancangan penyimpanan data visual berbasis Internet of Things (IoT) dengan menggunakan aplikasi Android dan media penyimpanan awan (cloud storage) meliputi potensi dan masalah, pengumpulan data, desain produk, validasi desain, revisi desain, ujicoba produk, revisi produk, dan ujicoba pemakaian. Materi penelitian adalah software Android Studio yang merupakan Integrated Development Enviroment (IDE) untuk sistem operasi Android, Internet of Things (IoT), dan media penyimpanan Firebase.

Tahapan penelitian meliputi (1) tahap identifikasi potensi dan masalah adalah potensi internet yang telah merambah kepedesaan, dan adanya permasalahan 
dengan kondisi lahan pertanian yang perlu mendapatkan solusi penyelesaian secepatnya, (2) tahap pengumpulan data adalah pengumpulan informasi berupa kebutuhan petani akan pemecahan masalah yang cepat tanpa harus menunggu kunjungan lapangan penyuluh ataupun ahli pertanian dan ketersediaan sarana jaringan internet yang berhubungan erat dengan kecepatan analisis informasi yang berasal dari petani, (3) tahap desain produk adalah mendesain produk yang mudah digunakan dan menarik yang berguna untuk melakukan penyimpanan gambar hasil kamera android secara cepat dan aman ke penyimpanan awan Firebase (4) tahap validasi desain adalah menilai produk yang telah dirancang secara rasional, apakah mudah digunakan, dapat dengan cepat melakukan penyimpanan data gambar, dan mudah diakses untuk melakukan analisis gambar, (5) tahap revisi desain adalah perbaikan kelemahan desain berdasarkan validasi, berupa ketepatan penempatan tombol upload dan download agar mudah dalam pelaksanaannya, (6) tahap uji coba produk adalah uji coba penggunaan produk dengan melakukan pengambilan gambar dan melakukan upload, serta melakukan download untuk melihat hasil gambar yang diambil oleh kamera android, (7) tahap revisi produk adalah perbaikan kelemahan produk setelah uji coba, berupa perbaikan upload dan download sehingga mudah diakses, (8) tahap uji coba pemakaian adalah produk diberikan kepada pemakai untuk digunakan dalam hal ini mengadakan pengambilan gambar pada lahan pertanian dan selanjutnya melakukan upload gambar keadaan pertanaman di area pertanian, serta melakukan analisis gambar oleh analis pertanian dan juga memberikan informasi akan kekurangan atau hambatan dalam pemakaian produk tersebut.

Penelitian meliputi pembuatan ruang penyimpanan pada firebase dengan software Android Studio di mana gambar yang dihasilkan kamera dengan bantuan aplikasi Mobile Firebase Cloud storage akan tersimpan pada penyimpanan awan Firebase. Pengguna (klien) aplikasi firebase yang telah dibuat dengan software Android Studio, melakukan registrasi pada Firebase sebagai penyedia layanan real time database untuk dapat menggunakan Firebase sebagai media penyimpanan awan. Setelah registrasi, maka pengguna (klien) dapat mengakses data yang berada pada Firebase dari mana saja dan kapan saja dengan berbagai platform sepanjang terhubung dengan internet. Adapun arsitektur sistem database Firebase disajikan pada Gambar 1.

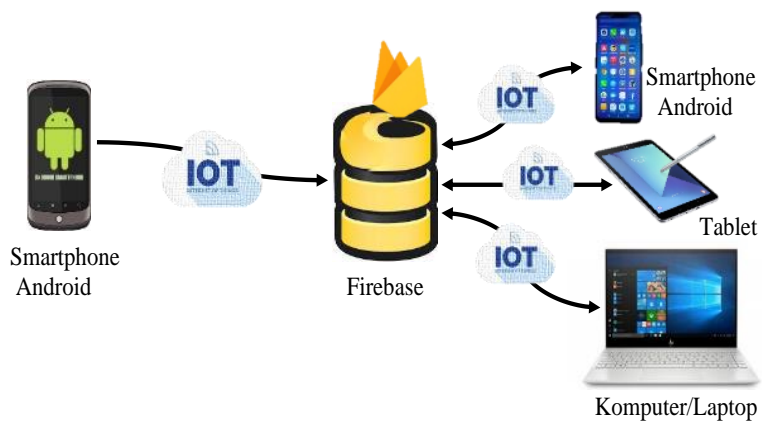

Gambar 1. Arsitektur Sistem Database Firebase

Dalam penelitian ini akan dilakukan pengambilan gambar melalui kamera handphone dan menyimpan gambar ke database Firebase (sebagai cloud cloud storage yang besar dan aman) dengan bantuan Mobile Firebase Cloud storage melalui Internet of Things yang dapat diakses oleh pengguna (klien) setiap saat, dari mana saja, dan dari berbagai platform. Langkah-langkah untuk melakukan penyimpanan ke database Firebase disajikan pada Gambar 2.

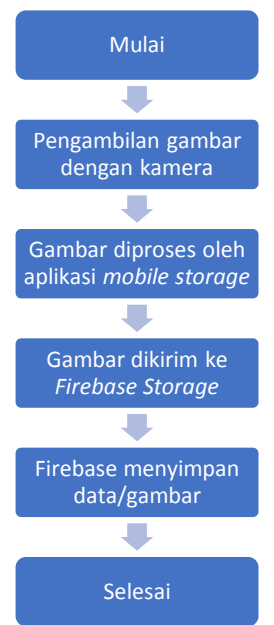

Gambar 2. Flowchart Sistem Penyimpanan Gambar ke Database Firebase

Pada Flowchart, langkah pertama yang dilakukan oleh pengguna adalah mengambil gambar dengan menggunakan kamera handphone, selanjutnya pengguna membuka aplikasi mobile Firebase Cloud storage dan memilih gambar untuk diupload, selanjutnya aplikasi mengupload gambar tersebut ke Firebase Cloud storage, dan yang terakhir gambar tersebut tersimpan di Firebase Cloud storage.

Use Case Diagram daripada sistem penyimpanan gambar ke database Firebase disajikan pada Gambar 3. 


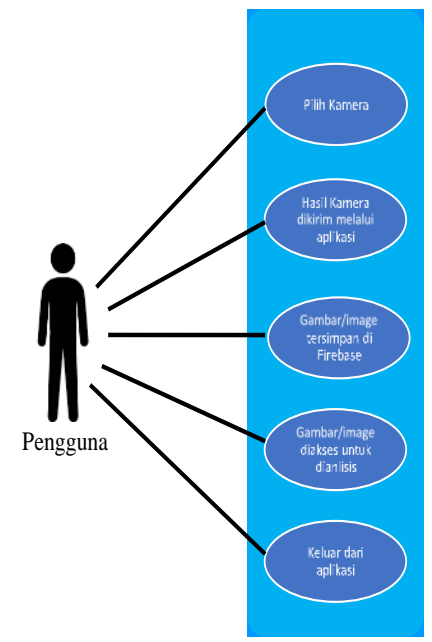

Gambar 3. Use Case Diagram Penyimpanan Gambar ke Database Firebase

Pada Use Case Diagram, pengguna memilih aplikasi kamera untuk mengambil gambar, selanjutnya pengguna memilih aplikasi Mobile Firebase Cloud storage untuk mengirim gambar ke Firebase Cloud storage, selanjutnya pengguna membuka browser untuk masuk ke Firebase Cloud storage untuk mengambil gambar untuk dianalisis, setelah semuanya telah dilakukan, pengguna dapat keluar dari aplikasi dan browser.

Adapun Activity Diagram daripada sistem penyimpanan gambar ke database Firebase pada Android disajikan pada Gambar 4.

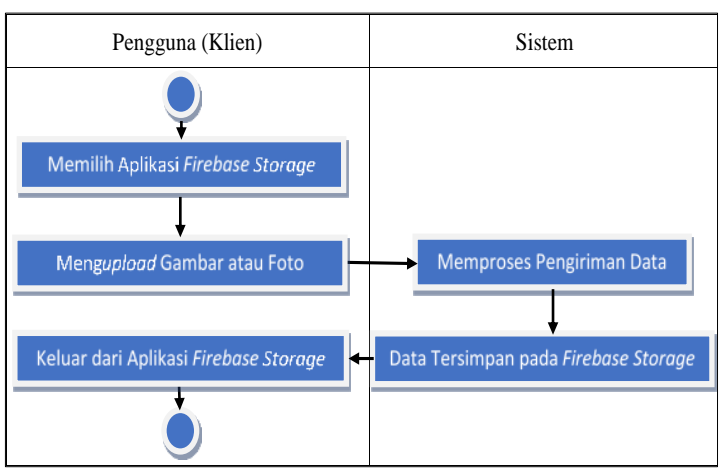

Gambar 4. Activity Diagram Penyimpanan Gambar ke Database Firebase

Pada Activity Diagram, pengguna membuka aplikasi Mobile Firebase Cloud storage, selanjutnya pengguna mengupload gambar dan sistem akan memproses pengiriman gambar tersebut ke Firebase Cloud storage, setelah sistem berhasil megirimkan gambar tersebut ke Firebase Cloud storage, pengguna dapat keluar dari aplikasi.

Class Diagram yang merupakan alur penyimpanan gambar ke database firebase dalam aplikasi ini serta hubungannya satu dengan lainnya disajikan pada Gambar 5.

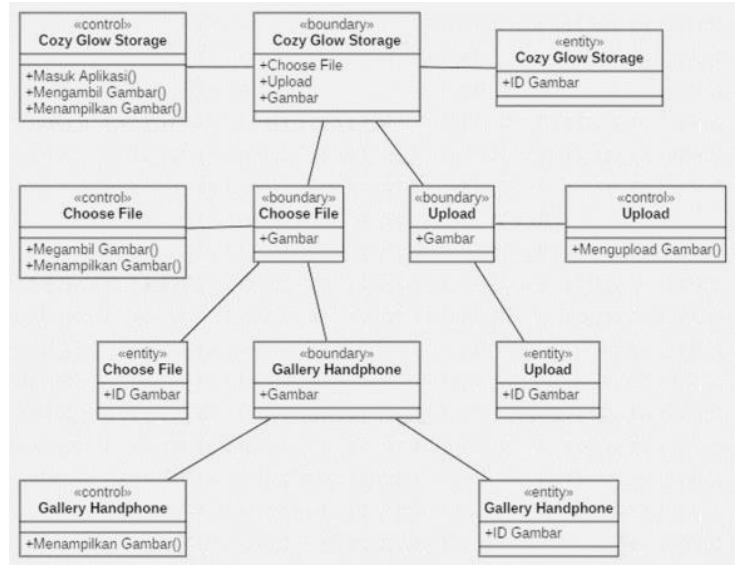

Gambar 5. Class Diagram Penyimpanan Gambar ke Database Firebase

Jumlah Class yang digunakan pada Class Diagram adalah 12 kelas yang terbagi atas 4 bagian kelas besar, yaitu Cozy Glow Cloud storage, Choose File, Upload, dan Gallery Handphone. Pada bagian control setiap kelas besar memiliki operation yang digunakan, selanjutnya pada bagian entity setiap besar memiliki attribute ID Gambar yang digunakan untuk membaca ID setiap gambar yang digunakan, dan pada bagian boundary setiap kelas besar memiliki attribute Gambar yang digunakan untuk menampilkan gambar yang digunakan.

\section{HASIL DAN PEMBAHASAN}

Adapun aplikasi yang sudah dihasilkan dari penelitian ini berupa aplikasi berbasis android yang terhubung secara langsung dengan penyimpanan Firebase. Untuk tahap awal dilakukan pembuatan aplikasi dengan Android Studio, setelah aplikasi selesai dibuat dengan menambahkan import dari Firebase, selanjutnya dilakukan aktifasi Firebase pada Android Studio.
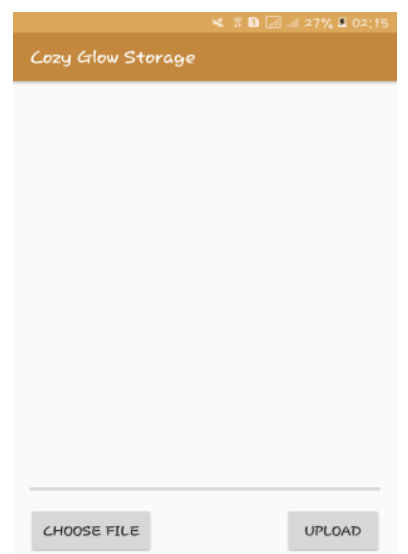

Gambar 6. Halaman Utama Aplikasi Cozy Glow Cloud storage 
Setelah membuka aplikasi, maka akan masuk ke halaman utama aplikasi. Gambar 6 menampilkan halaman utama aplikasi, pada halaman utama terdapat tombol choose file untuk memilih gambar apa yang mau dimasukkan dan tombol upload untuk mengupload gambar ke firebase cloud storage.

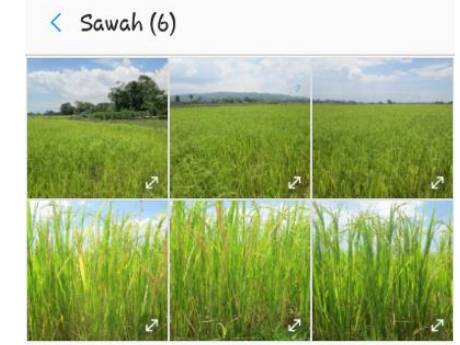

Gambar 7. Halaman Gallery Handphone dari Aplikasi Cozy Glow Cloud storage

Setelah memilih tombol choose file, aplikasi akan masuk ke dalam gallery handphone dan menampilkan semua gambar yang ada di gallery handphone seperti yang terlihat pada Gambar 7. Setelah memilih gambar yang akan dimasukkan, aplikasi akan menampilkan gambar tersebut.

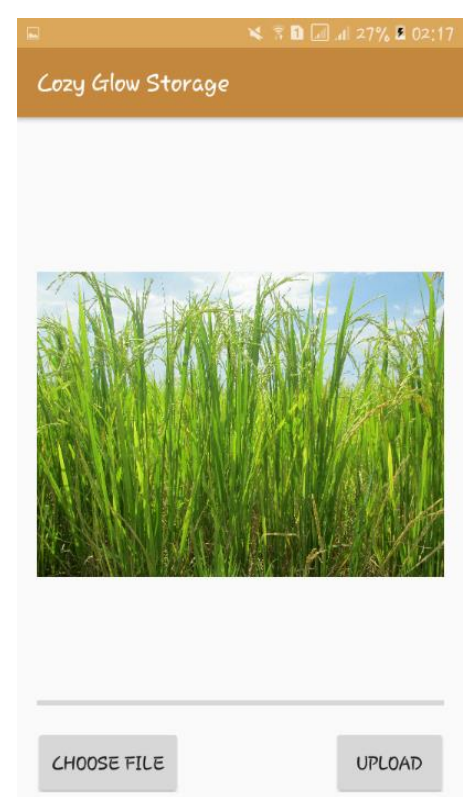

Gambar 8. Aplikasi menampilkan Gambar yang akan di upload
Setelah memilih gambar yang akan dimasukkan, aplikasi akan menampilkan gambar tersebut seperti yang terlihat pada Gambar 8. Selanjutnya memilih tombol upload dan aplikasi akan memproses gambar tersebut ke firebase cloud storage. Setelah aplikasi memproses gambar tersebut, gambar tersebut berhasil tersimpan ke firebase cloud storage.

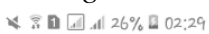

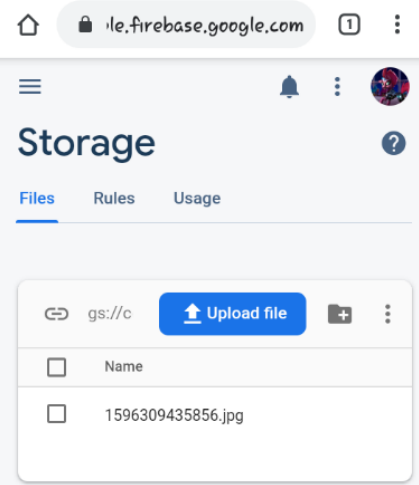

Gambar 9. Halaman Firebase Cloud storage

Gambar 9 menampilkan halaman firebase cloud storage, pada halaman tersebut terdapat file gambar untuk di download. Pada halaman firebase cloud storage juga terdapat tombol upload file untuk mengupload file langsung dari firebasenya.

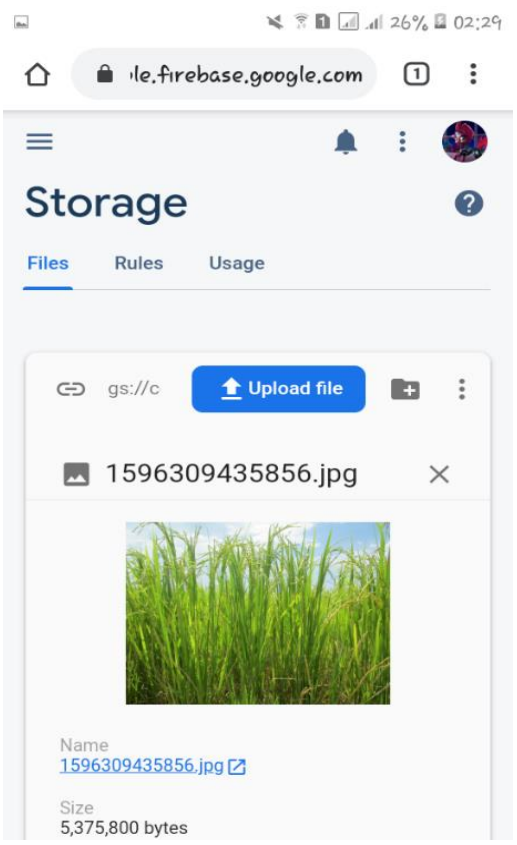

Gambar 10. Halaman Firebase Cloud storage menampilkan gambar yang akan di download 
Kemudian pilih gambar tersebut dan firebase akan menampilkan gambar tersebut untuk di download seperti yang terlihat pada Gambar 10. Selanjutnya pilih link yang berwarna biru untuk menampilkan gambarnya dalam ukuran penuh.

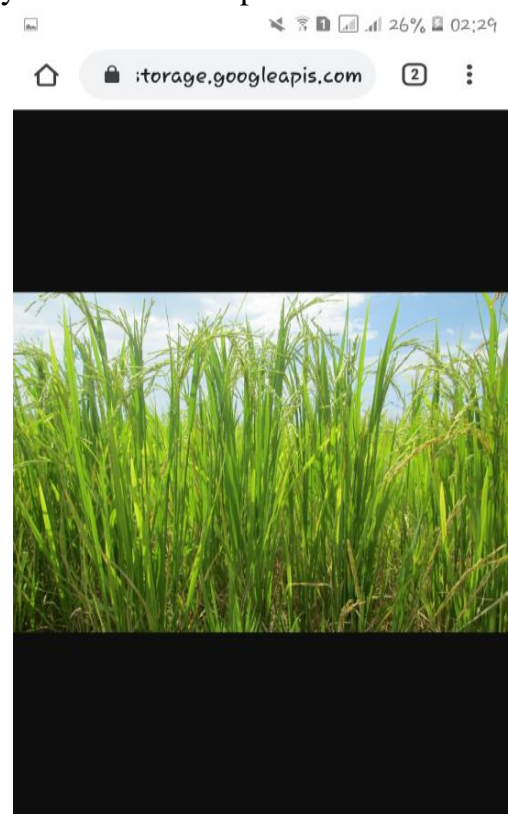

Gambar 11. Halaman Browser menampilkan gambar yang akan di download

Setelah memilih gambar tesebut, halaman browser akan menampilkan gambar tersebut untuk siap di download seperti yang terlihat pada Gambar 11 . Selanjutnya tahan agak lama gambar tersebut untuk menampilkan pilihan untuk mendownload gambar tersebut.

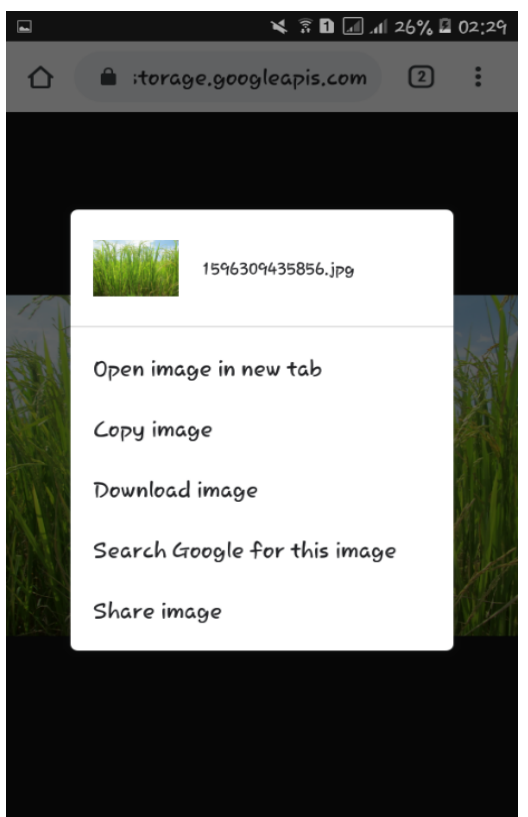

Gambar 12. Halaman Browser menampilkan pilihan untuk mendownload gambar
Setelah halaman browser menampilkan gambar tesebut, selanjutnya tekan gambar tersebut sedikit lama lalu akan tampil pilihan untuk open image in new tab, download image, dan share image seperti yang terlihat pada Gambar 12. Kemudian pilih download image, maka gambar tersebut akan tersimpan ke dalam gallery handphone.

1. implementation 'com.google.firebase:firebase-storage:16.0.4'

Gambar 13. Library Firebase

Gambar 13 merupakan library firebase yang harus ditambahkan pada method dependencies pada build gradle app pada Android Studio. Kode Program ini merupakan library firebase storage, ini digunakan untuk mengakses dan melakukan pengolahan storage pada firebase.

1. implementation 'com.google.firebase:firebase-database:16.0.4'

2. implementation 'com.google.firebase:firebase-core:16.0.4'

Gambar 14. Library Firebase

Gambar 14 merupakan library firebase yang harus ditambahkan pada method dependencies pada build gradle app pada Android Studio. Pada baris perintah ke-1 merupakan library firebase database, ini digunakan untuk mengakses dan melakukan pengolahan database pada firebase. Pada aplikasi ini menggunakan versi 16.0.4. Pada baris yang ke-2 merupakan library utama firebase.

\footnotetext{
1. import com.google.firebase.database.DatabaseReference;

2. import com.google.firebase.database.FirebaseDatabase;

3. import com.google.firebase.storage.FirebaseStorage;

4. import com.google.firebase.storage.OnProgressListener;

5. import com.google.firebase.storage.StorageReference;

6. import com.google.firebase.storage.StorageTask;

7. import com.google.firebase.storage.UploadTask;
}

\section{Gambar 15. Import Library Firebase}

Gambar 15 merupakan import library firebase yang harus ditambahkan pada main activity pada Android Studio. Pada baris perintah ke-1 merupakan import library firebase database reference, ini digunakan untuk membaca firebase database yang digunakan. Pada baris yang ke-2 merupakan import library firebase database, ini digunakan untuk membaca isi firebase database yang digunakan. Pada baris yang ke3 merupakan import library firebase storage, ini digunakan untuk membaca isi firebase storage yang digunakan. Pada baris yang ke-4 merupakan import library firebase storage progress listener, ini digunakan untuk mendata isi firebase storage yang digunakan. Pada baris yang ke-5 merupakan import library firebase storage reference, ini digunakan untuk membaca firebase storage yang digunakan. Pada baris yang ke-6 merupakan import library firebase storage 
task, ini digunakan untuk membaca pekerjaan firebase storage yang digunakan. Pada baris yang ke-7 merupakan import library firebase upload task, ini digunakan untuk membaca pekerjaan mengupload data ke firebase storage yang digunakan.

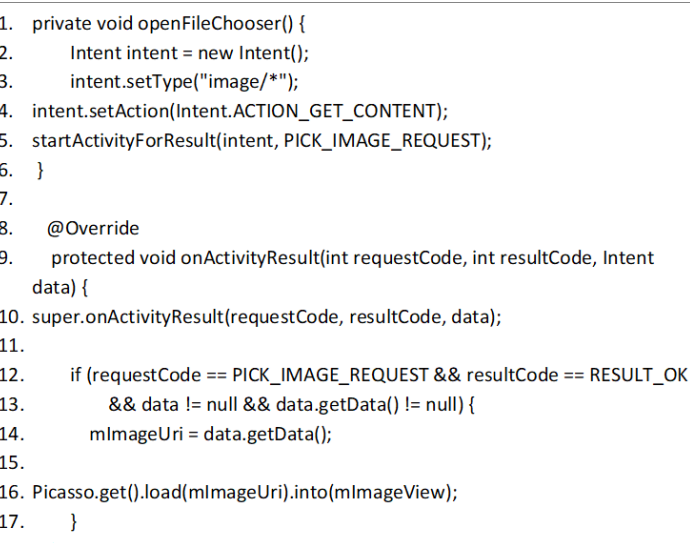

\section{Gambar 16. Main Activity}

Gambar 16 merupakan code yang harus ditambahkan pada main activity pada Android Studio. Pada baris 1-6 merupakan open file chooser, ini digunakan untuk membaca dan memilih file yang berformat gambar dari gallery handphone. Pada baris 8-18 merupakan activity result, ini digunakan untuk mengrequest gambar dari gallery handphone untuk diupload ke firebase storage.

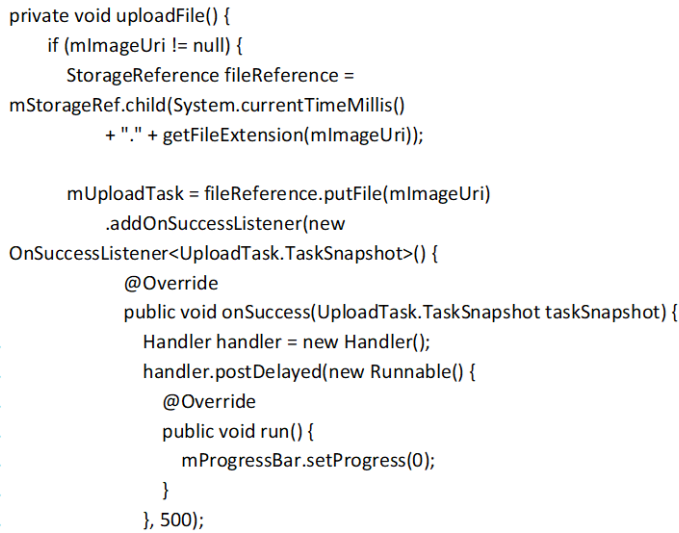

\section{Gambar 17. Upload File}

Gambar 17 merupakan code yang harus ditambahkan pada main activity pada Android Studio. Pada baris 1-16 merupakan upload file, ini digunakan untuk mengupload file gambar dari gallery handphone ke firebase storage.

Aplikasi diuji dengan melakukan pengujian fungsi-fungsi dari aplikasi untuk mencari kesalahan/bug pada sistem. Adapun maksud dari melakukan pengujian aplikasi ini adalah agar sistem dapat berjalan sesuai yang diharapkan serta memenuhi kebutuhan penggunanya. Dalam pengujian aplikasi ini digunakan dua cara yaitu pengujian alpha dan pengujian beta. Dalam pengujian alpha digunakan metode Blackbox yaitu menguji fungsi-fungsi aplikasi tanpa memperhatikan alur eksekusi program. Perhatian utama dalam pengujian alpha adalah kesesuaian rancangan dan yang diharapkan. Hasil pengujian alpha dari aplikasi disajikan pada Tabel 1.

Tabel 1. Pengujian Alpha

\begin{tabular}{|c|c|c|c|c|}
\hline $\begin{array}{l}\text { Fungsi } \\
\text { yang } \\
\text { diuji }\end{array}$ & $\begin{array}{l}\text { Kond } \\
\text { isi }\end{array}$ & $\begin{array}{l}\text { Output } \\
\text { yang } \\
\text { diharapk } \\
\text { an }\end{array}$ & $\begin{array}{l}\text { Output } \\
\text { yang } \\
\text { dihasilk } \\
\text { an }\end{array}$ & $\begin{array}{l}\text { Status } \\
\text { Pengu } \\
\text { jian }\end{array}$ \\
\hline $\begin{array}{l}\text { Tombo } \\
1 \\
\text { Choose } \\
\text { File }\end{array}$ & $\begin{array}{l}\text { Mena } \\
\text { mpilk } \\
\text { an } \\
\text { semu } \\
\text { a } \\
\text { gamb } \\
\text { ar } \\
\text { dari } \\
\text { galler } \\
y \\
\text { hand } \\
\text { phone }\end{array}$ & $\begin{array}{l}\text { Sukses } \\
\text { menamp } \\
\text { ilkan } \\
\text { semua } \\
\text { gambar } \\
\text { dari } \\
\text { gallery } \\
\text { handpho } \\
\text { ne }\end{array}$ & $\begin{array}{l}\text { Sukses } \\
\text { menamp } \\
\text { ilkan } \\
\text { semua } \\
\text { gambar } \\
\text { dari } \\
\text { gallery } \\
\text { handpho } \\
\text { ne }\end{array}$ & Valid \\
\hline $\begin{array}{l}\text { Tombo } \\
1 \\
\text { Upload }\end{array}$ & $\begin{array}{l}\text { Uplo } \\
\text { ad } \\
\text { gamb } \\
\text { ar ke } \\
\text { fireba } \\
\text { se } \\
\text { stora } \\
\text { ge }\end{array}$ & $\begin{array}{l}\text { Sukses } \\
\text { upload } \\
\text { gambar } \\
\text { ke } \\
\text { firebase } \\
\text { storage }\end{array}$ & $\begin{array}{l}\text { Sukses } \\
\text { upload } \\
\text { gambar } \\
\mathrm{ke} \\
\text { firebase } \\
\text { storage }\end{array}$ & Valid \\
\hline $\begin{array}{l}\text { Kemud } \\
\text { ahan } \\
\text { IoT }\end{array}$ & $\begin{array}{l}\text { Meng } \\
\text { akses } \\
\text { fireba } \\
\text { se } \\
\text { stora } \\
\text { ge }\end{array}$ & $\begin{array}{l}\text { Sukses } \\
\text { mengaks } \\
\text { es } \\
\text { firebase } \\
\text { storage }\end{array}$ & $\begin{array}{l}\text { Sukses } \\
\text { mengaks } \\
\text { es } \\
\text { firebase } \\
\text { storage }\end{array}$ & Valid \\
\hline $\begin{array}{l}\text { Downl } \\
\text { oad } \\
\text { File }\end{array}$ & $\begin{array}{l}\text { Down } \\
\text { load } \\
\text { file } \\
\text { dari } \\
\text { fireba } \\
\text { se } \\
\text { stora } \\
\text { ge }\end{array}$ & $\begin{array}{l}\text { Sukses } \\
\text { downloa } \\
\text { d file } \\
\text { dari } \\
\text { storage }\end{array}$ & $\begin{array}{l}\text { Sukses } \\
\text { downloa } \\
\text { d file } \\
\text { dari } \\
\text { storage }\end{array}$ & Valid \\
\hline
\end{tabular}

Pengujian selanjutnya adalah pengujian beta dengan membuat instrumen kuesioner untuk mengetahui tanggapan pengguna aplikasi berbasis Android dengan media penyimpanan Firebase ini, dengan membuat 5 butir pertanyaan kepada 20 petani 
modern. Pada Tabel 2, jawaban responden berupa Sangat Setuju (SS), Setuju (S), Cukup Setuju (CS), Tidak Setuju (TS), dan Sangat Tidak Setuju (STS) diberi skor untuk melakukan pengukuran dengan skala Likert. Adapun skor $\mathrm{SS}=5, \mathrm{~S}=4, \mathrm{KS}=3$, TS=2, $\mathrm{STS}=1$, sehingga untuk keadaan ideal maka akan memilih SS sehingga nilai ideal (Y) adalah 5 (skor tertinggi) x 20 (jumlah responden $)=100$.

Tabel 2. Index Persentase

\begin{tabular}{|l|l|l|}
\hline No & Pertanyaan & Index \\
\hline 1 & $\begin{array}{l}\text { Apakah aplikasi mudah } \\
\text { digunakan? }\end{array}$ & $87 \%$ \\
\hline 2 & $\begin{array}{l}\text { Apakah proses pemilihan } \\
\text { dan upload gambar } \\
\text { mudah dilakukan? }\end{array}$ & $84 \%$ \\
\hline 3 & $\begin{array}{l}\text { Apakah aplikasi mudah } \\
\text { terhubung dengan } \\
\text { Internet of Things? }\end{array}$ & $\begin{array}{l}\text { Apakah proses download } \\
\text { dan share gambar di } \\
\text { Firebase mudah } \\
\text { dilakukan }\end{array}$ \\
\hline 5 & $\begin{array}{l}\text { Apakah secara } \\
\text { keseluruhan penggunaan } \\
\text { fitur pada Aplikasi Cozy } \\
\text { Glow Storage dan } \\
\text { Firebase mudah } \\
\text { dipahami dan digunakan } \\
?\end{array}$ & $82 \%$ \\
\hline
\end{tabular}

\begin{tabular}{|c|l|c|}
\hline No & \multicolumn{1}{|c|}{ Pertanyaan } & Index \\
\hline 1 & Apakah aplikasi mudah digunakan? & $87 \%$ \\
\hline 2 & Apakah proses pemilihan dan upload gambar mudah dilakukan? & $84 \%$ \\
\hline 3 & Apakah aplikasi mudah terhubung dengan Internet of Things? & $85 \%$ \\
\hline 4 & $\begin{array}{l}\text { Apakah proses download dan share gambar di Firebase mudah } \\
\text { dilakukan? }\end{array}$ & $78 \%$ \\
\hline 5 & $\begin{array}{l}\text { Apakah secara keseluruhan penggunaan fitur-fitur pada Cozy } \\
\text { Glow Storage dan Firebase mudah dipahami dan digunakan } \\
\text { (friendly)? }\end{array}$ & $82 \%$ \\
\hline
\end{tabular}

Hasil yang disajikan pada Tabel 2 untuk pertanyaan nomor $1,2,3$, dan 5 berada pada kriteria Sangat Setuju, dan pertanyaan nomor 4 berada pada kriteria Setuju. Dengan demikian berdasarkan pengujian alpha dan beta menunjukkan bahwa aplikasi mudah digunakan dan fitur-fiturnya mudah dipahami.

Hasil yang diperoleh dari responden disajikan pada Tabel 2. Hasil untuk pertanyaan pertama adalah 9 responden (SS), 9 responden (S), dan 2 responden (CS), sehingga hasilnya adalah $((9 \times 5)+(9 \times 4)+(2 \times 3)) / 100 \times$ $100 \%=87 \%$. Untuk pertanyaan kedua adalah 5 responden (SS), 14 responden $(\mathrm{S})$, dan 1 responden (CS), sehingga hasilnya adalah $((5 \times 5)+(14 \times 4)+(1 \times 3)) /$ $100 \times 100 \%=84 \%$. Untuk pertanyaan ketiga adalah 10 responden (SS), 6 responden (S), 3 responden (CS), dan 1 responden (TS), sehingga hasilnya adalah
$((10 \times 5)+(6 \times 4)+(3 \times 3)+(1 \times 2)) / 100 \times 100 \%=85 \%$. Untuk pertanyaan keempat adalah 6 responden (SS), 8 responden (S), 4 responden (CS), dan 2 responden (TS), sehingga hasilnya adalah $((6 \times 5)+(8 \times 4)+(4 \times 3)+(2 \times 2)) / 1$ $00 \times 100 \%=78 \%$. Untuk pertanyaan kelima adalah 7 responden (SS), 9 responden $(\mathrm{S}), 3$ responden $(\mathrm{CS})$, dan 1 responden (TS), sehingga hasilnya adalah $((7 \times 5)+(9 \times 4)+(3 \times 3)+(1 \times 2)) / 100 \times 100 \%=82 \%$.

\section{KESIMPULAN}

Berdasarkan hasil penelitian menunjukkan bahwa aplikasi mobile firebase cloud storage merupakan aplikasi yang sangat diperlukan untuk melakukan penyimpanan data gambar ke Firebase dengan cepat. Gambar atau foto keadaan pertanaman pertanian yang diambil menggunakan kamera handphone android dengan bantuan aplikasi mobile firebase cloud storage dapat dengan cepat diterima oleh analis pertanian yang melakukan akses ke firebase yang selanjutnya dapat memberikan petunjuk pemecahan masalah secara cepat pula kepada petani berdasarkan data gambar yang terdapat pada firebase, tanpa harus melakukan kunjungan lapangan. Data gambar pada Firebase sangat mudah diakses, baik untuk aktivitas upload maupun aktivitas download dan dapat dilakukan kapan saja dan di mana saja sepanjang terhubung dengan Internet of Things.

\section{DAFTAR PUSTAKA}

[1] B. Sunaryo, M. I. Rusydi, J. F. Rusdi, R. Suriani, and S. Daus, "Sistem Pelacakan Lokasi Pelaporan Petugas Lapangan Irigasi Provinsi Sumatera Barat Berbasis GPS Smartphone dan WebGIS," J. RESTI (Rekayasa Sist. dan Teknol. Informasi), vol. 3, no. 2, pp. 271-281, 2019, doi: 10.29207/resti.v3i2.957.

[2] Google Cloud, "Cloud Storage," Tersedia: https://cloud.google.com/storage, [Diakses: 18 Mei 2020].

[3] C. Khawas and P. Shah, "Application of Firebase in Android App Development-A Study," Int. J. Comput. Appl., vol. 179, no. 46, pp. 49-53, 2018, doi: 10.5120/ijca2018917200.

[4] H. Kristomson, R. H. Subrata, and F. Gozali, "Sistem Keamanan Ruangan Berbasis Internet Of Things Dengan Menggunakan Aplikasi Android," TESLA J. Tek. Elektro, vol. 20, no. 2, pp. 127-134, 2019, doi: 10.24912/tesla. v20i2.2989.

[5] A. Sonita and R. F. Fardianitama, "Aplikasi EOrder Menggunakan Firebase dan Algoritme 
Knuth Morris Pratt Berbasis Android," Pseudocode, vol. V, no. 2, pp. 38-45, 2018, doi: 10.33369/pseudocode.5.2.38-45.

[6] M. Ilhami, "Pengenalan Google Firebase Untuk Hybrid Mobile Apps Berbasis Cordova," J. IT CIDA, vol. 3, no. 1, pp. 16-29, 2017.

[7] R. Azariah, Solomon R Inbamani, "Android Controlled Surveillance Robot Using Firebase," Int. J. Innov. Res. Sci. Eng. Technol., vol. 7, no. 11, pp. 9248-9255, 2018, [Online]. Available: http://www.ijirset.com/upload/2018 /november/16_Android.pdf.

[8] M. Ramli, D. J. Mamahit, and J. O. Wuwung, "Rancang Bangun Sistem Pemantau Tamu Pada Smart Home Berbasis Raspberry PI 3," Ejournal Tek. Elektro dan Komput., vol. 7, no. 1, pp.1-8,2018, doi:10.35793/jtek.7.1.2018. 19085

[9] D. Edwin and R. Somya, “Aplikasi Inventori menggunakan Teknologi Firebase (Studi Kasus: PT. Asindo Setiatama)," Artikel Ilmiah, Program Studi Teknik Informatika, Fakultas Teknologi Informasi, Universitas Kristen Satya Wacana, Salatiga, 2017.

[10] G. R. Paraya and R. Tanone, "Penerapan Firebase Realtime Database Pada Prototype Aplikasi Pemesanan Makanan Berbasis Android," J. Tek. Inform. dan Sist. Inf., vol. 4, no. 3, pp. 397-406, 2018

[11] V. H. P. Tjandra and N. Setiyawati, "Perancangan Aplikasi E-Voting Berbasis Android Dengan Teknologi Firebase (Studi Kasus : Pemilihan Ketua HMP FTI UKSW)," J. SITECH Sist. Inf. dan Teknol., vol. 2, no. 1, pp. 21-30, 2019, doi: 10.24176/sitech.v2i1. 3164.

[12] Android, "What is Android," Tersedia: https:// www.android.com/what-is-android/, [Diakses: 20 Mei 2020].

[13] Firebase, "Product," Tersedia: https://firebase. google.com/products, [Diakses: 20 Mei 2020].

[14] Salma, R. F. Olanrewaju, and M. M. Arman, "Smart parking guidance system using 360o camera and haar-cascade classifier on IoT system," Int. J. Recent Technol. Eng., vol. 8, no. 2S11, pp. 864-872, 2019, doi: 10.35940/ ijrte.B1142.0982S1119.

[15] S. E. Princy and K. G. J. Nigel, "Implementation of cloud server for real time data storage using Raspberry $\mathrm{Pi}$," in IC-GET 2015 - Proceedings of 2015 Online
International Conference on Green Engineering and Technologies, 2015, pp. 1-4, doi: 10.1109/GET.2015.7453790.

[16] S. B. V. Krishna, J. Oviya, S. Gowri, and M. Varshini, "Cloud robotics in industry using Raspberry Pi," in 2nd International Conference on Science Technology Engineering and Management, ICONSTEM, 2016, pp. 543-547, doi: 10.1109/ICONSTEM.2016.7560952. 